\title{
Assessment Of Lung Function And Its Correlation With Anthropometric Measurements In Selected Population In Manipal
}

\section{Guruprasad Rao}

Melaka Manipal Medical College

Barathi Singaravel Subramaniam ( $\sim$ barathi.ss@manipal.edu )

Manipal Academy of Higher Education https://orcid.org/0000-0001-8534-7051

\section{Sowmiya Rajeswaran}

Melaka Manipal Medical College

Anne Tan Lixin

Melaka Manipal Medical College

Nurul Atsaya

Melaka Manipal Medical College

Pariksha Pillai

Melaka Manipal Medical College

Kallaiarasi Chandran

Melaka Manipal Medical College

\section{Research}

Keywords: lung function, peak expiratory flow rate, vital capacity, occupation, exposure

Posted Date: July 22nd, 2020

DOI: https://doi.org/10.21203/rs.3.rs-45017/v1

License: (9) This work is licensed under a Creative Commons Attribution 4.0 International License. Read Full License 


\section{Abstract}

Background: Lung function test is a useful indicator that measures the presence of mild abnormalities, if any. The present study aimed to compare the lung function in people from different occupations and to correlate with anthropometric measurements and blood pressure.

Methods: This cross-sectional study was conducted among students, faculty, gardeners, housekeeping, and support staff of Melaka Manipal Medical College (MMMC) and auto drivers of Manipal. Peak expiratory flow rate (PEFR) and vital capacity (VC) were recorded using a digital spirometer. Breathholding time (BHT), and blood pressure (BP) were recorded. Waist-to-hip ratio (WHR) and body mass index (BMI) were measured. The data were analyzed using the Prism statistical package.

Results: Forty-one males and Thirty-two females participated in this study. PEFR did not significantly differ among the different occupations but was negatively correlated with WHR in females. For VC, male students showed a significantly higher value than gardeners, whereas female students and faculty members had a considerably higher value than housekeepers. VC negatively correlated with age in males. In females, it showed a negative correlation with age, WHR, duration of indoor non-AC exposure, and systolic BP. BHT of male students and staff was significantly higher than auto drivers, and it showed a negative correlation with age, duration of outdoor exposure, and systolic BP. Lung function parameters did not correlate with indoor AC exposure in males and females. Systolic BP was significantly higher in auto drivers than students, and it increased with age in males. In females, systolic BP negatively correlated with outdoor exposure and positively correlated with indoor non-AC exposure. Among females, WHR was significantly higher in housekeepers and staff than students and faculty.

Conclusion: The study results showed that vital capacity was lowest among male gardeners and female housekeepers who tend to have occupational exposure to chemicals. Peak expiratory flow rate (PEFR) and vital capacity were lower in females with a tendency towards abdominal obesity. More considerable time spent indoors was associated with lower vital capacity and higher systolic blood pressure in females.

\section{Introduction}

Lung function test or spirometry is a useful test to measure the change in the lung volume during the forced breathing technique. The pulmonary function tests objectively quantify lung function and help detect the presence of mild abnormalities and also defining the exact type. The measurement of the peak expiratory flow rate is a handy tool in the diagnosis and management of bronchial asthma, and it also helps to predict the status of lung function.(1) The breath-holding time is used in determining the breaking point when the ventilatory drive becomes stronger. Furthermore, the vital capacity measurement helps in assessing the ventilatory functions of the lung in healthy and diseased conditions. Lung function test is also helpful in monitoring the outcome of the rehabilitation process and even in epidemiological studies in the general population.(2) 
Recent guidelines have stressed maintaining healthy lifestyles for the prevention of diseases, including stroke, myocardial infarction, hypertension, diabetes, and asthma. Several risk factors such as body weight, blood glucose, serum cholesterol, and blood pressure are known to be associated with the increased risk of lifestyle disorders.(3-6) Studies have mentioned that apart from the risk factors mentioned above, different psychosocial factors also play a significant role in the development of cardio embolic disorders. Among these factors, the most important one is long working hours and a sedentary lifestyle. Long working hours are the common problems found in Asia, Europe and in USA.(7)

While spending most waking hours at work, people face a variety of health hazards, including the incidence of chronic diseases. On the other hand, people working outdoors for long, are exposed to toxic pollutants in the atmosphere. The studies have shown that recently air pollution is a major health concern affecting the overall health of an individual.(8) The respiratory system bears the major brunt of the toxic pollutants in the atmosphere. Occupational exposure to indoor and outdoor air pollution can lead to significant health effects and can lead to compromised lung function.(9)

Moreover, studies have also pointed out that body mass index (BMI) has a significant association with lung function. Previously, a study conducted among obese individuals reported that lung function declines with an increase in BMI.(10) However, very less information is available on the correlation of lung function test with the anthropometric parameters and blood pressure in the general population. Therefore, the present study aimed to assess the lung function parameters in people engaged in different occupations and to correlate these parameters with anthropometric measurements and blood pressure.

\section{Materials And Methods}

This cross-sectional study was conducted among students, faculty, gardeners, housekeeping, and support staff of Melaka Manipal Medical College (MMMC) and auto drivers of Manipal. Before the start of the study, ethical clearance was obtained from the institutional ethics committee. People with no previous history of any respiratory diseases, respiratory infection in the last two months and who were not using prescribed bronchodilators were included in the study. Before the start of the study, informed consent was obtained from all the participants. Lung function parameters such as peak expiratory flow rate and vital capacity were recorded using a digital spirometer, and breath-holding time was recorded manually. BMI, waist-to-hip ratio, and blood pressure (BP) were recorded to determine the correlation with lung function. For blood pressure, both the systolic and diastolic blood pressure were recorded after 5 minutes rest and a two-minute break. The data were analyzed using the Prism statistical package.

\section{Results}

In this study, a total of 73 participants were included comprising $43.8 \%(n=41)$ females and $56.16 \%(n=$ 32) males. The peak expiratory flow rate in males and females showed no significant difference from each other $(p>0.05)$, however in females, negative correlation $[r=-0.4462(p<0.05)]$ with WHR were observed. (Fig. 1) 
Among the male students, the vital capacity showed a significantly higher value than gardeners $(p<0.01)$ (Fig. 2), whereas female students and faculty members had a significantly higher value than housekeepers $(p<0.001)$ (Fig. 3$)$. In males, vital capacity showed a negative correlation $[r=-0.4734(p<$ $0.01)]$ with age and in females it was negatively correlated with age $[r=-0.4768(p<0.01)]$, with indoor non - AC exposure $[r=-0.6758(p<0.01)]$, with anthropometric measurements $[r=-0.5895(p<0.001)]$ and with systolic blood pressure $[r=-0.3581(p<0.05)]$.

Breath- holding time of male students and staffs were significantly higher than auto drivers $(p<0.05)$ (Fig. 4), whereas in females none of the group means were significantly different from each other $(p>$ $0.05)$. In males, breath-holding time showed negative correlation with age $[r=-0.5279(p<0.001)]$, with outdoor exposure $[r=-0.5495(p<0.001)]$, with systolic blood pressure $[r=-0.3383(p<0.05)]$ and in females, it showed negative correlation with systolic blood pressure $[r=-0.4149(p<0.05)]$.

In males and females, no correlation of indoor AC exposure with any lung function parameters was observed. Besides, systolic blood pressure in auto drivers was higher than students $(p<0.01)$.

Systolic blood pressure showed positive correlation $[r=0.3909(p<0.05)]$ with age in males and positive correlation $[r=0.4928(p<0.05)]$ with indoor non-AC exposure in females and also negative correlation $[r$ $=-0.3688(p<0.05)]$ with outdoor exposure in females (Fig. 5). As for diastolic blood pressure, none of the group means were significantly different from each other $(p>0.05)$ but it showed positive correlation $[r=0.3663(p<0.05)]$ with age in males. The body mass index was not significantly different among the groups $(p>0.05)$.

No significant correlation of BMI in both genders with lung function parameters or blood pressure was observed. None of the group means of anthropometric measurements in males were significantly different from each other $(p>0.05)$. In contrast, the waist to hip ratio in female housekeepers and staff was higher than students and faculty members $(p<0.001)$. However, there was no significant correlation between anthropometric measurements in males with lung function parameters or blood pressure.

\section{Discussion}

The lung function test is an indicator of the working capacity of the lungs. Studies have pointed out that in individuals with a decline in the forced expiratory volume in one second effectively increases the risk of death. Therefore, assessing the lung function in every individual is useful in healthcare systems and should be practiced widely.(11) In the studies conducted by Mannino et al., the researchers have opined that the decline in lung function is positively associated with COPD and death.(12-14)

In the present study, it was observed that vital capacity was lowest among male gardeners and female housekeepers who tend to have occupational exposure to chemicals. A study conducted in coal miners reported that exposure to dust particles significantly affects the lung function test. Moreover, it was also reported that exposure to dust particles could even cause emphysema.(15) 
In another study conducted in Iran, it was observed that male participants who get exposed to increased dust particles have an increased incidence of obstructive lesions.(16) In the present study, PEFR did not significantly differ among the different occupations but was negatively correlated with WHR in females.

Lung function depends on various factors. Among them, some are environmental, and some are genetic factors. Studies have also shown that different communities have different pulmonary functions. In this study, we found that breath-holding time was lower among auto drivers. This could be due to older age and outdoor exposure. Some earlier studies reported that outdoor exposure to various particles such as dust, fuels, exhaust or fumes significantly decreases the lung function tests.(17-19)

On the other hand, vital capacity and peak expiratory flow rate in auto drivers were not significantly affected in this study compared to studies conducted at other areas (20), which could be due to lesser pollution rates in Manipal and also since auto drivers wear masks showing a higher level of awareness.

In some previous studies the investigators have shown that different factors such as gender, race, ethnicity, weight, and height, affect the pulmonary function test.(21-25) In another study conducted in Iran, it was also mentioned that air-borne particles also affect the pulmonary function test.(26) some studies has also shown an association of decline in lung function among individuals exposed to occupational dust particles.(27-33)

However, a direct comparison between the results reported in this study and other study results is not possible as the anthropometric parameters used in this study are different from other studies reported previously. Moreover, in the Indian scenario, the association of working hours and pulmonary function test data is scarce.

Peak expiratory flow rate (PEFR) and vital capacity were lower in females with a tendency towards abdominal obesity. More considerable time spent indoors was associated with lower vital capacity and higher systolic BP in females.

Vital capacity in males was negatively correlated with age. On the other hand, in females, it showed a negative correlation with the duration of indoor non-AC exposure. However, no statistically significant correlation was seen with indoor AC exposure in males and females. In a previous study, it was shown that forced vital capacity gets significantly affected by the use of AC. Moreover, it was also reported that $\mathrm{AC}$ users have a predisposition to developing respiratory disorders. (34-40)

Systolic BP was significantly higher in auto drivers than students, and it increased with age in males. This result was found to be similar to the previous studies reported. In previous studies, it was pointed out that girls usually have a lower systolic BP compared with boys. $(41,42)$

Furthermore, it was also reported that with the increase in age, the rise in the blood pressure is more among males compared with the females. Even it was shown that in western countries after 40 years of age, the blood pressure increases by approximately seven $\mathrm{mmHg}$ in every decade. $(43,44)$ 
The present study also reported that in females, systolic BP negatively correlated with outdoor exposure and positively correlated with indoor non-AC exposure. Among females, WHR was significantly higher in housekeepers and staff than students and faculty.

\section{Conclusion}

The study result indicates that the presence of chemicals can change the vital capacity of individuals. Peak expiratory flow rate (PEFR) and vital capacity were lower in females with a tendency towards abdominal obesity. More significant time spent indoors was associated with lower vital capacity and higher systolic blood pressure in females.

\section{Declarations}

\section{Ethics approval and consent to participate}

This study was approved by the institutional ethics committee on $13^{\text {th }}$ June 2018 vide IEC:373/278

\section{Consent for publication}

Not Applicable

\section{Availability of data and materials}

All data and materials are described in the manuscript.

\section{Competing interests}

Not Applicable

\section{Funding}

None

\section{Authors' contributions}

GP and BSS conceptualized, designed, and reviewed the study.

SR, ATL, NA, PP, K and BSS conducted the study, collected the data.

GP \& BSS wrote the manuscript. The authors read and approved the final manuscript 


\section{Acknowledgements}

Dr Ullas Kamath , for permitting to use the infrastructure and the participants for their cooperation

\section{References}

1. Mrindha MA-A, Amin MR, Kabir AL. Peak Expiratory Flow Rate (PEFR)-A Simple Ventilatory Lung Function Test. J Shaheed Suhrawardy Med Coll. 2012;3(2):44-7.

2. Mohammed J, Maiwada S, Sumaila F. Relationship between anthropometric variables and lung function parameters among primary school children. Ann Niger Med [Internet]. 2015;9(1):20-5. Available from: http://www.anmjournal.com/text.asp?2015/9/1/20/163331.

3. Piepoli MF, Hoes AW, Agewall S, Albus C, Brotons C, Catapano AL, et al. 2016 European Guidelines on cardiovascular disease prevention in clinical practice. Eur Heart J. 2016;37(29):2315-81.

4. Piepoli MF, Hoes AW, Agewall S, Albus C, Brotons C, Catapano AL, et al. 2016 European Guidelines on cardiovascular disease prevention in clinical practice the Sixth Joint Task Force of the European Society of Cardiology and Other Societies on Cardiovascular Disease Prevention in Clinical Practice (constituted by representativ. Eur J Prev Cardiol. 2016.

5. Piepoli MF, Hoes AW, Agewall S, Albus C, Brotons C, Catapano AL, et al. 2016 European guidelines on cardiovascular disease prevention in clinical practice. The Sixth Joint Task Force of the European Society of Cardiology and Other Societies on Cardiovascular Disease Prevention in Clinical Practice (constituted by representati. G Ital Cardiol (Rome). 2017.

6. Ryden L, Grant PJ, Anker SD, Berne C, Cosentino F, Danchin N, et al. ESC Guidelines on diabetes, prediabetes, and cardiovascular diseases developed in collaboration with the EASD - Summary The Task Force on diabetes, pre-diabetes, and cardiovascular diseases of the European Society of Cardiology (ESC) and developed in col. Diabetes Vasc Dis Res. 2014;11(3):133-73.

7. Virtanen M, Magnusson Hansson L, Goldberg M, Zins M, Stenholm S, Vahtera J, et al. Long working hours, anthropometry, lung function, blood pressure and blood-based biomarkers: Cross-sectional findings from the CONSTANCES study. J Epidemiol Community Health. 2019;73(2):130-5.

8. 10.5339/avi.2013.9

Teather K, Hogan N, Critchley K, Gibson M, Craig S, Hill J. Examining the links between air quality, climate change and respiratory health in Qatar. Avicenna [Internet]. 2013 Jul;(2013):9. Available from: http://www.qscience.com/doi/abs/10.5339/avi.2013.9.

9. World Health Organization. Air pollution_Household air pollution: Pollutants [Internet]. Available from: http://www.who.int/airpollution/household/pollutants/en/.

10. 10.1186/1465-9921-9-31

Thyagarajan B, Jacobs DR, Apostol GG, Smith LJ, Jensen RL, Crapo RO, et al. Longitudinal association of body mass index with lung function: The CARDIA Study. Respir Res [Internet]. 2008 Dec 4;9(1):31. Available from: https://respiratoryresearch.biomedcentral.com/articles/10.1186/1465-9921-9-31. 
11. $10.1136 /$ oem. 2006.031419

Sircar K, Hnizdo E, Petsonk E, Attfield M. Decline in lung function and mortality: implications for medical monitoring. Occup Environ Med [Internet]. 2007 Jul 1;64(7):461-6. Available from: http://oem.bmj.com/cgi/doi/10.1136/oem.2006.031419.

12. Mannino DM, Gagnon RC, Petty TL, Lydick E. Obstructive Lung Disease and Low Lung Function in Adults in the United States. Arch Intern Med [Internet]. 2000 Jun 12;160(11):1683-9. Available from: http://archinte.jamanetwork.com/article.aspx?doi=10.1001/archinte.160.11.1683.

13. Mannino DM, Homa DM, Akinbami LJ, Ford ES, Redd SC. Chronic obstructive pulmonary disease surveillance-United States, 1971-2000. MMWR Surveill Summ Morb Mortal Wkly report Surveill Summ / CDC. 2002.

14. Mannino DM, Ford ES, Redd SC. Obstructive and restrictive lung disease and functional limitation: Data from the Third National Health and Nutrition Examination. J Intern Med. 2003.

15. $10.1164 /$ rccm.200806-8400C

Kuempel ED, Wheeler MW, Smith RJ, Vallyathan V, Green FHY. Contributions of Dust Exposure and Cigarette Smoking to Emphysema Severity in Coal Miners in the United States. Am J Respir Crit Care Med [Internet]. 2009 Aug;180(3):257-64. Available from:

http://www.atsjournals.org/doi/abs/10.1164/rccm.200806-8400C.

16. Ahmadial N, Khamnei S, Abedinzadeh M, Najafi H, Mohammadi M. Lung function reference values in Iranian adolescents. East Mediterr Health J [Internet]. 2006 Nov;12(6):834-9. Available from: http://www.ncbi.nlm.nih.gov/pubmed/17333830.

17. 10.1016/j.sjbs.2020.01.019

Ahmad I, Balkhyour MA. Occupational exposure and respiratory health of workers at small scale industries. Saudi J Biol Sci [Internet]. 2020;27(3):985-90. Available from:

https://doi.org/10.1016/j.sjbs.2020.01.019.

18. $10.1093 /$ aje/kwf105

Hnizdo E. Association between Chronic Obstructive Pulmonary Disease and Employment by Industry and Occupation in the US Population: A Study of Data from the Third National Health and Nutrition Examination Survey. Am J Epidemiol [Internet]. 2002 Oct 15;156(8):738-46. Available from: https://academic.oup.com/aje/article-lookup/doi/10.1093/aje/kwf105.

19. Becklake MR. Occupational exposures: Evidence for a causal association with chronic obstructive pulmonary disease. American Review of Respiratory Disease. 1989.

20. Farooque I, Jayachandra S. Pulmonary function tests in nonsmoking auto rickshaw drivers. Al Amin J Med Sci. 2014;7(3):240-3.

21. Bandyopadhyay A. Pulmonary function studies in young healthy Malaysians of Kelantan, Malaysia. Indian J Med Res. 2011.

22. A comparative study of FVC. FEV1, and TLC in non-smoking Saudi students at Eastern Province, Saudi Arabia with Caucasian reference values. Eur Respir J. 2012. 
23. K GC,S, K S, R N. L.S. D. Pulmonary function studies in young healthy students of Haryana. Indian Journal of Physiology and Pharmacology. 2012.

24. Bandyopadhyay A, Bhattacharjee I, Dalui R, Pal S. Pulmonary function studies of healthy nonsmoking male university students of Kolkata, India - revisited. Malaysian J Med Sci. 2013.

25. Bandyopadhyay A, Dalui R, Pal S, Bhattacharjee I, Goswami B, Roy AS. Pulmonary function in young females of Kolkata, India - Revisited. Physiol Int. 2016.

26. Amarloei A, Jonidi Jafari A, Mahabadi HA silia., Asadollahi K, Nourmoradi H. Investigation on the Lung Function of General Population in Ilam, West of Iran, as a City Exposed to Dust Storm. Glob J Health Sci [Internet]. 2015 Jan 13;7(3):298-308. Available from:

http://www.ccsenet.org/journal/index.php/gjhs/article/view/41103.

27. Kauffmann F, Drouet D, Ellouch JL, Brille D. Occupational exposure and 12-year spirometric changes among Paris area workers. $\mathrm{Br} \mathrm{J}$ Ind Med. 1982.

28. Ulvestad B, Bakke B, Eduard W, Kongerud J, Lund MB. Cumulative exposure to dust causes accelerated decline in lung function in tunnel workers. Occup Environ Med. 2001.

29. Johnsen HL, Hetland SM, Benth J, Kongerud J, Søyseth V. Dust Exposure Assessed by a Job Exposure Matrix Is Associated with Increased Annual Decline in FEV 1. Am J Respir Crit Care Med. 2010.

30. Jacobsen G, Schlünssen V, Schaumburg I, Taudorf E, Sigsgaard T. Longitudinal lung function decline and wood dust exposure in the furniture industry. Eur Respir J. 2008.

31. Jacobsen GH, Schlünssen V, Schaumburg I, Sigsgaard T. Cross-shift and longitudinal changes in FEV1 among wood dust exposed workers. Occup Environ Med. 2013.

32. Johnsen HL, Bugge MD, Føreland S, Kjuus H, Kongerud J, Søyseth V. Dust exposure is associated with increased lung function loss among workers in the Norwegian silicon carbide industry. Occup Environ Med. 2013.

33. J GH, I. S VS. T. S. Cross-shift and longitudinal changes in FEV1 among wood dust exposed workers. Occup Environ Med. 2013.

34. Khaliq F, Sharma S, Tandon OP. Pulmonary functions in air conditioner users. Indian J Physiol Pharmacol. 2006;50(1):67-72.

35. Babitha R, Rangarajan R, Muhil M, Basavarajaiah MG. Pulmonary function tests in air conditioner users. J Clin Diagnostic Res. 2011;5(3):532-5.

36. Hulke S, Thakare A, Patil P, Shete S, Vaidya Y. Pulmonary functions in air conditioner users. Med J Dr DY Patil Univ [Internet]. 2013;6(1):21. Available from: http://www.mjdrdypu.org/text.asp? 2013/6/1/21/108629.

37. Sabade SB, Vikhe BB, Borade NG. Pulmonary ventilation in air conditioner users in pravara rural hospital. Pravara Med Rev. 2013;5(2):4-6.

38. Vidya G, Kumar B, Kalpana M, Chand K. Pulmonary function tests in air conditioner users. Int J Med Biomed Res [Internet]. 2014 Jul 26;3(2):75-80. Available from: 
http://www.ijmbr.com/reviewed/3.2.3.pdf.

39. FUNCTIONS IN HEALTHY MALES IN AND AROUND RAICHUR CITY Jeelani M, Ahmed MM. EFFECT OF AIR CONDITIONER ON PULMONARY. FUNCTIONS IN HEALTHY MALES IN AND AROUND RAICHUR CITY. J Evid Based Med Healthc [Internet]. 2015 May 6;2(19):2816-21. Available from: http://www.jebmh.com/data_pdf/02 - Jeelani - 2.pdf.

40. Vincent SHJR. L. Pulmonary functions in car air conditioner users and non-air conditioner users in tertiary care centre, South Tamilnadu, India. Int J Res Med Sci [Internet]. 2019 Aug 27;7(9):3510. Available from: https://www.msjonline.org/index.php/ijrms/article/view/6896.

41. Syme C, Abrahamowicz M, Leonard GT, Perron M, Richer L, Veillette S, et al. Sex Differences in Blood Pressure and Its Relationship to Body Composition and Metabolism in Adolescence. Arch Pediatr Adolesc Med [Internet]. 2009 Sep 7;163(9):818-25. Available from: http://archpedi.jamanetwork.com/article.aspx?doi=10.1001/archpediatrics.2009.92.

42. Pausova Z, Mahboubi A, Abrahamowicz M, Leonard GT, Perron M, Richer L, et al. Sex differences in the contributions of visceral and total body fat to blood pressure in adolescence. Hypertension. 2012.

43. WITH AGE? Lancet [Internet] Mottram RF. DOES BLOOD-PRESSURE RISE. WITH AGE? Lancet [Internet]. 1981 Aug;318(8244):468. Available from: https://linkinghub.elsevier.com/retrieve/pii/S0140673681907923.

44. 10.1161/HYPERTENSIONAHA.111.189100 Gurven M, Blackwell AD, Rodríguez DE, Stieglitz J, Kaplan H. Does Blood Pressure Inevitably Rise With Age? Hypertension [Internet]. 2012 Jul;60(1):25-33. Available from: https://www.ahajournals.org/doi/10.1161/HYPERTENSIONAHA.111.189100.

\section{Tables}


Table 1

Details of lung function test in male study participants between different study groups

\section{PEFR}

\begin{tabular}{|llllll|}
\hline & Auto (M) & Student (M) & Gardeners (M) & Staff (M) & Faculty (M) \\
\hline N & 15 & 10 & 4 & 6 & 5 \\
\hline Mean & 467.1 & 513 & 417.5 & 455.4 & 560.5 \\
\hline Std. Deviation & 105.8 & 97.42 & 98.11 & 74.31 & 82.04 \\
\hline Std. Error & 27.33 & 30.81 & 49.05 & 30.34 & 36.69 \\
\hline Vital capacity & & & & & \\
\hline & Auto (M) & Student (M) & Gardeners (M) & Staff (M) & Faculty (M) \\
\hline N & 15 & 10 & 4 & 6 & 5 \\
\hline Mean & 2918 & 3640 & 2050 & 2965 & 3302 \\
\hline Std. Deviation & 763.6 & 527.5 & 420.3 & 273 & 833.4 \\
\hline Std. Error & 197.1 & 166.8 & 210.2 & 111.5 & 372.7 \\
\hline Breath-holding time & & & & \\
\hline & Auto (M) & Student (M) & Gardeners (M) & Staff (M) & Faculty (M) \\
\hline N & 15 & 10 & 4 & 6 & 5 \\
\hline Mean & 44.47 & 66.8 & 37.5 & 71.5 & 62.8 \\
\hline Std. Deviation & 13.5 & 19.38 & 18.23 & 25.7 & 14.15 \\
\hline Std. Error & 3.484 & 6.13 & 9.115 & 10.49 & 6.328 \\
\hline \multirow{2}{*}{15} & & & & 6 \\
\hline
\end{tabular}


Table 2

Details of lung function test in female study participants between different study groups

\begin{tabular}{|c|c|c|c|c|c|}
\hline \multicolumn{6}{|l|}{ PEFR } \\
\hline & $\begin{array}{l}\text { Student } \\
(F)\end{array}$ & $\begin{array}{l}\text { Housekeeping } \\
\text { (F) }\end{array}$ & Gardeners(F) & $\begin{array}{l}\text { Staff } \\
(\mathrm{F})\end{array}$ & $\begin{array}{l}\text { Faculty } \\
\text { (F) }\end{array}$ \\
\hline $\mathrm{N}$ & 11 & 10 & 3 & 3 & 5 \\
\hline Mean & 325.5 & 295 & 260 & 256.7 & 361 \\
\hline Std. Deviation & 46.12 & 39.79 & 45.83 & 55.08 & 75.06 \\
\hline Std. Error & 13.91 & 12.58 & 26.46 & 31.8 & 33.57 \\
\hline \multicolumn{6}{|l|}{ Vital capacity } \\
\hline & $\begin{array}{l}\text { Student } \\
(F)\end{array}$ & $\begin{array}{l}\text { Housekeeping } \\
(F)\end{array}$ & Gardeners(F) & $\begin{array}{l}\text { Staff } \\
(F)\end{array}$ & $\begin{array}{l}\text { Faculty } \\
\text { (F) }\end{array}$ \\
\hline $\mathrm{N}$ & 11 & 10 & 3 & 3 & 5 \\
\hline Mean & 2295 & 1490 & 1667 & 2100 & 2426 \\
\hline Std. Deviation & 325.9 & 299.8 & 57.74 & 200 & 581.1 \\
\hline Std. Error & 98.27 & 94.81 & 33.33 & 115.5 & 259.9 \\
\hline \multicolumn{6}{|l|}{ Breath-holding time } \\
\hline & $\begin{array}{l}\text { Student } \\
(F)\end{array}$ & Housekeep (F) & Gardeners $(F)$ & $\begin{array}{l}\text { Staff } \\
(F)\end{array}$ & $\begin{array}{l}\text { Faculty } \\
\text { (F) }\end{array}$ \\
\hline $\mathrm{N}$ & 11 & 10 & 3 & 3 & 5 \\
\hline Mean & 48.45 & 37.4 & 52.67 & 41.67 & 42.4 \\
\hline Std. Deviation & 10.15 & 21.46 & 15.18 & 3.786 & 11.35 \\
\hline Std. Error & 3.061 & 6.788 & 8.762 & 2.186 & 5.075 \\
\hline $\begin{array}{l}\text { Comparison by one way } \\
\text { ANOVA }\end{array}$ & \multicolumn{5}{|c|}{$\begin{array}{l}\text { None of the group means are significantly different from each other } \\
(p>0.05)\end{array}$} \\
\hline Spearman correlation & \multicolumn{5}{|c|}{ r value $=-0.4149(p<0.05)$ negative correlation with systolic BP } \\
\hline
\end{tabular}

\section{Figures}




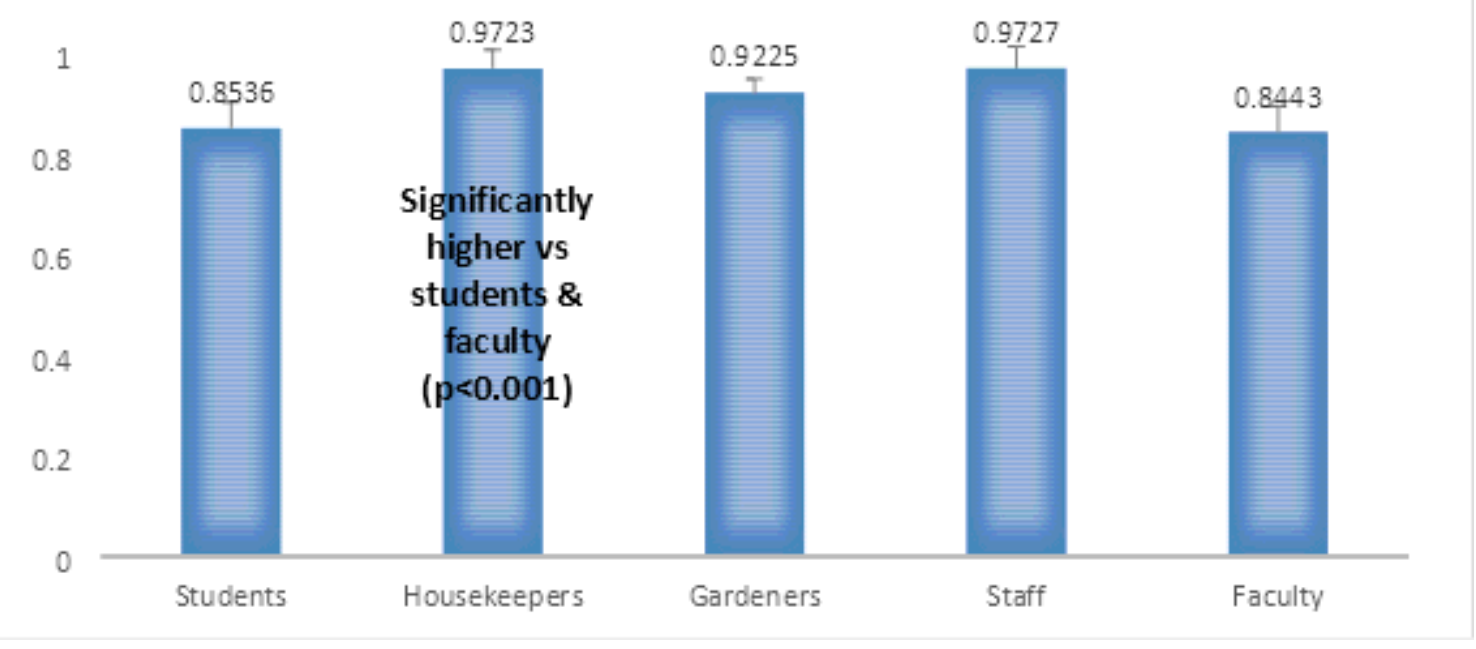

\section{Figure 1}

Waist-Hip Ratio Female

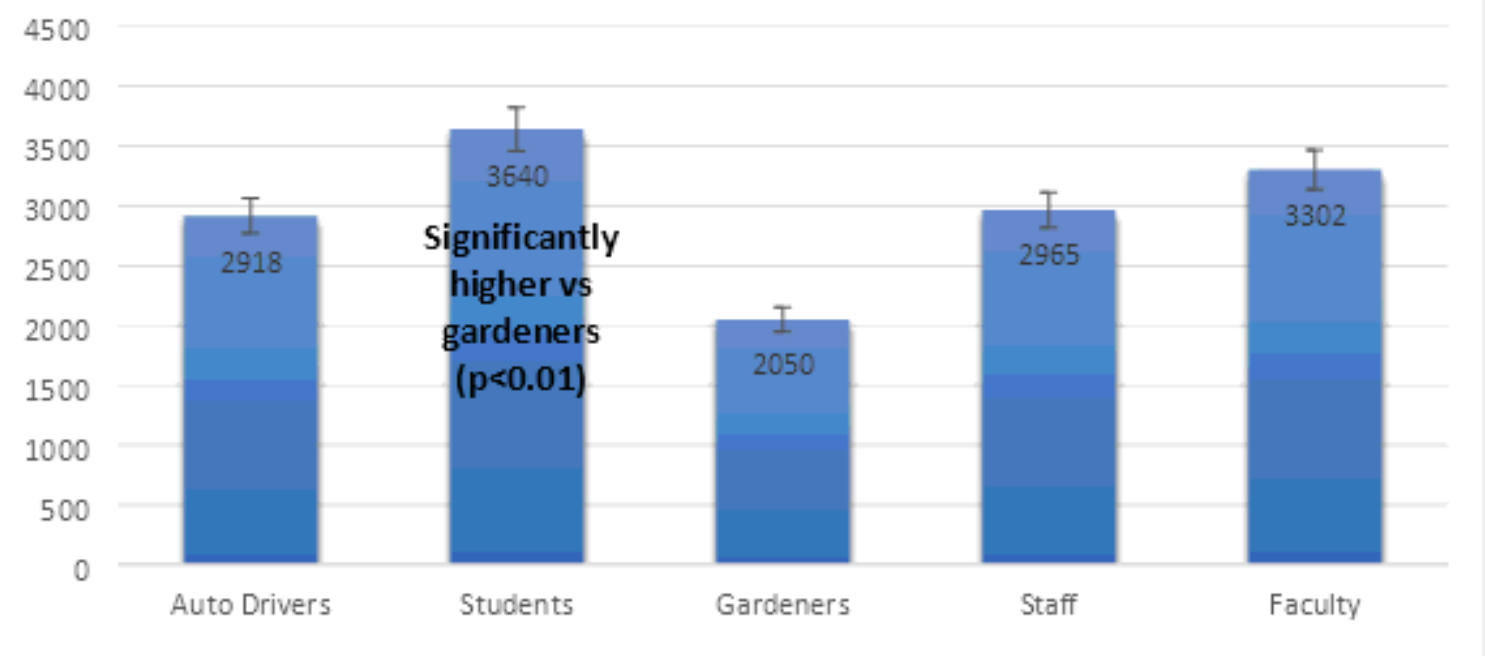

Figure 2

Vital Capacity (Males) 


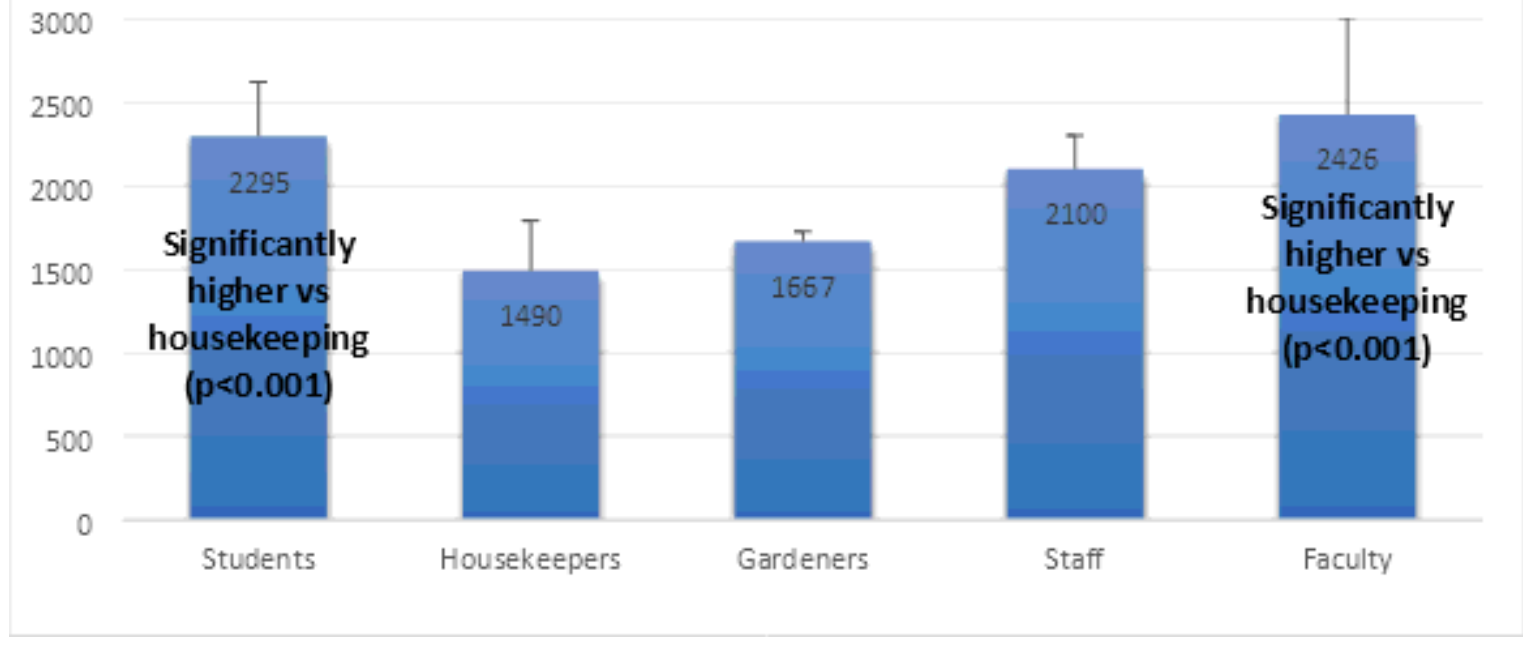

\section{Figure 3}

Vital Capacity (Females)

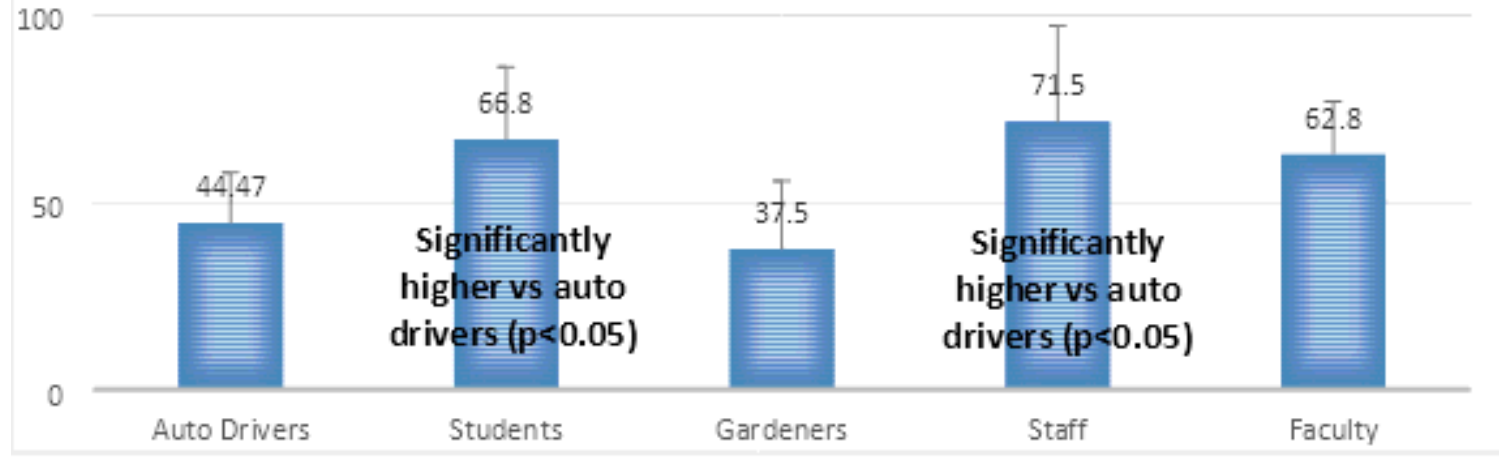

\section{Figure 4}

Breath Holding Time (M)

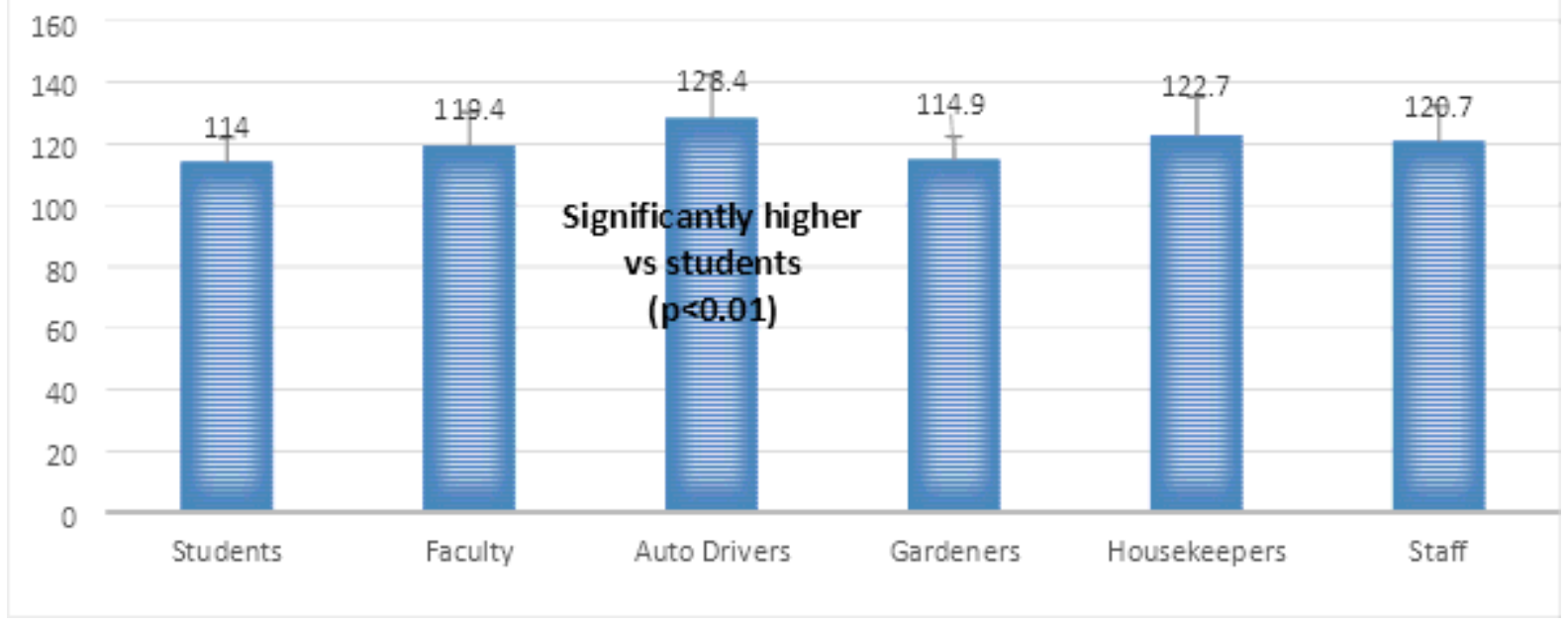


Figure 5

Systolic Blood Pressure

Page 15/15 